\title{
Application of Taxonomic Classification in Soil Fertility Management Using Maize (Zea mays L.) as Test Crop in Alfisols of Makurdi, Benue State
}

\author{
J. Usman, S. Idoga and O.J. Ogbu \\ Department of Soil Science, Federal University of Agriculture, Makurdi \\ Jakusman05@gmail.com
}

Keywords: Taxonomic Classification, Soil Fertility Management, Alfisols and Maize.

\begin{abstract}
The Alfisols of Makurdi Local Government Area of Benue State was studied with the aimed to characterize and classify the soils and determine the optimum fertilizer rate for maize production on the selected soil type of the study area. The soils were formed on Makurdi sand stone, deep $(141 \mathrm{~cm})$ and well drained. They were coarse-textured and moderately acidic in reaction ( $\mathrm{pH} 6.6-7.0$ ). They had low organic carbon contents ranging from 3.36 to $3.78 \%$ and high base saturation of $58.6 \%$ to $77.4 \%$. Based on the physical and chemical characteristics, the soils were classified as Eutric Ochrustalfs/Eutric Luvisols. In terms of growth parameters; plant height and number of leaves were not significantly different while leaf area, leaf area index and the stem diameter were significantly different. The highest $(130.60 \mathrm{~cm}, 12.30$ and $79.88 \mathrm{~mm})$ plant height, number of leaves and stem diameter were observed at the rate of NPK 150:75:75 kg/ha of fertilizer. In terms of yield parameters, ear weight and grain yield were not statistically significant whereas, ear length and ear diameter were statistically significant. However, NPK 60:30:30 kg/ha showed the highest (178 g) ear weight while application of NPK 150:75:75 kg/ha gave the highest $(2.82 \mathrm{~kg})$ grain yield. Since there was no significant difference between the fertilizer rates, it could be concluded that the minimum application rate (NPK 60:30:30 kg/ha) should be used in cultivating maize in Alfisols of Makurdi instead of the highest or the blanket recommendation which involved higher cost.
\end{abstract}

\section{Introduction}

It is no secret that the worlds demand for food especially grains is accelerating as population and per capita consumption increase at an unprecedented rate. The quest to grow food to meet that demand and feed the world population will continue to be one of the most important issues of our time. To counter the growing food insecurity, attention must be given to the soils due mainly because it is a vital resource to the sustenance of human and animal existence on earth. Soils are the loose mineral or organic materials $25 \%$ air, $25 \%$ water, $45 \%$ mineral and $5 \%$ organic matter (humus, tiny living organisms and sometimes plant residue). Intensification of agriculture on land currently used for traditional farming requires a thorough knowledge of the soil as a resource and attributes of the land. Information on distribution, potential and constraints of major soils is needed, so that the most appropriate soil management systems can be designed. In addition knowledge on soil taxonomic classification is also essential to determine the best land use for sustained crop production.

\section{Materials and Methods}

\section{Area of Study}

Makurdi lies on both banks of river Benue. It is bordered on the west by Keana, north by Lafia and Doma Local Government in Nasarawa State, on the east by Guma Local Government and the south by Gwer and Gwer-West Local Government. It is located between latitude $7^{\circ} 43^{\prime} \mathrm{N}$ and longitude $8^{\circ} 31^{\prime} \mathrm{E}$ of the Greenwich meridian. Makurdi has mean temperature ranging from $24.5^{\circ} \mathrm{C}$ 
and $30.3^{\circ} \mathrm{C}$. The weather conditions during the growing season of this study in 2017 and 2018 are as shown in Table 1.

Table 1: Weather data at the experimental site during the 2017 and 2018 growing seasons

\begin{tabular}{lllllll}
\hline Month & Rainfall (mm) & $\begin{array}{l}\text { No. of } \\
\text { days }\end{array}$ & rainfall & $\begin{array}{l}\text { Relative Humidity } \\
\text { 1500UTC-4.00pm } \\
\text { LT0900 UTC-100am LT }\end{array}$ & $\begin{array}{l}\text { Temperature } \\
\text { Pro }\end{array}$ & $\begin{array}{l}\text { Tem } \\
\left({ }^{0} \mathrm{C}\right) \text { Max., Min. }\end{array}$ \\
\hline 2017 & & & & & \\
April & 107.0 & 8 & 70.47 & $36.3,25.7$ \\
May & 208.9 & 8 & 78.63 & $33.2,24.5$ \\
June & 139.2 & 12 & 80.68 & $32.1,23.8$ \\
July & 108.2 & 11 & 84.70 & $31.0,22.5$ \\
August & 224.3 & 18 & 82.70 & $30.1,22.9$ \\
2018 & & & & \\
April & 47.9 & 4 & 68.49 & $36.1,24.7$ \\
May & 230.1 & 9 & 80.67 & $32.5,23.7$ \\
June & 144.1 & 11 & 79.68 & $31.4,22.8$ \\
July & 145.5 & 14 & 83.69 & $30.8,22.2$ \\
August & 275.5 & 21 & 83.73 & \\
\hline
\end{tabular}

Annual rainfall of the areas ranged from $1100 \mathrm{~mm}$ to about $2000 \mathrm{~mm}$, and its distribution is characterized by two peak periods (July and September) separated by a short August break. The relative humidity ranges from $50.4 \%$ to $92.6 \%$ (Adamgbe and Ujoh, 2012). The study area lies within the middle Benue trough consisting of a sedimentary terrain, and igneous rocks at the northern part. The sedimentary terrain comprises mainly sandstone of Makurdi Sandstone with common fold axes trending Southwest-Northeast (Burke et al., 1970). The major road which runs through parts of the area is the Makurdi-Naka road (Maud and Ozibo, 2017).

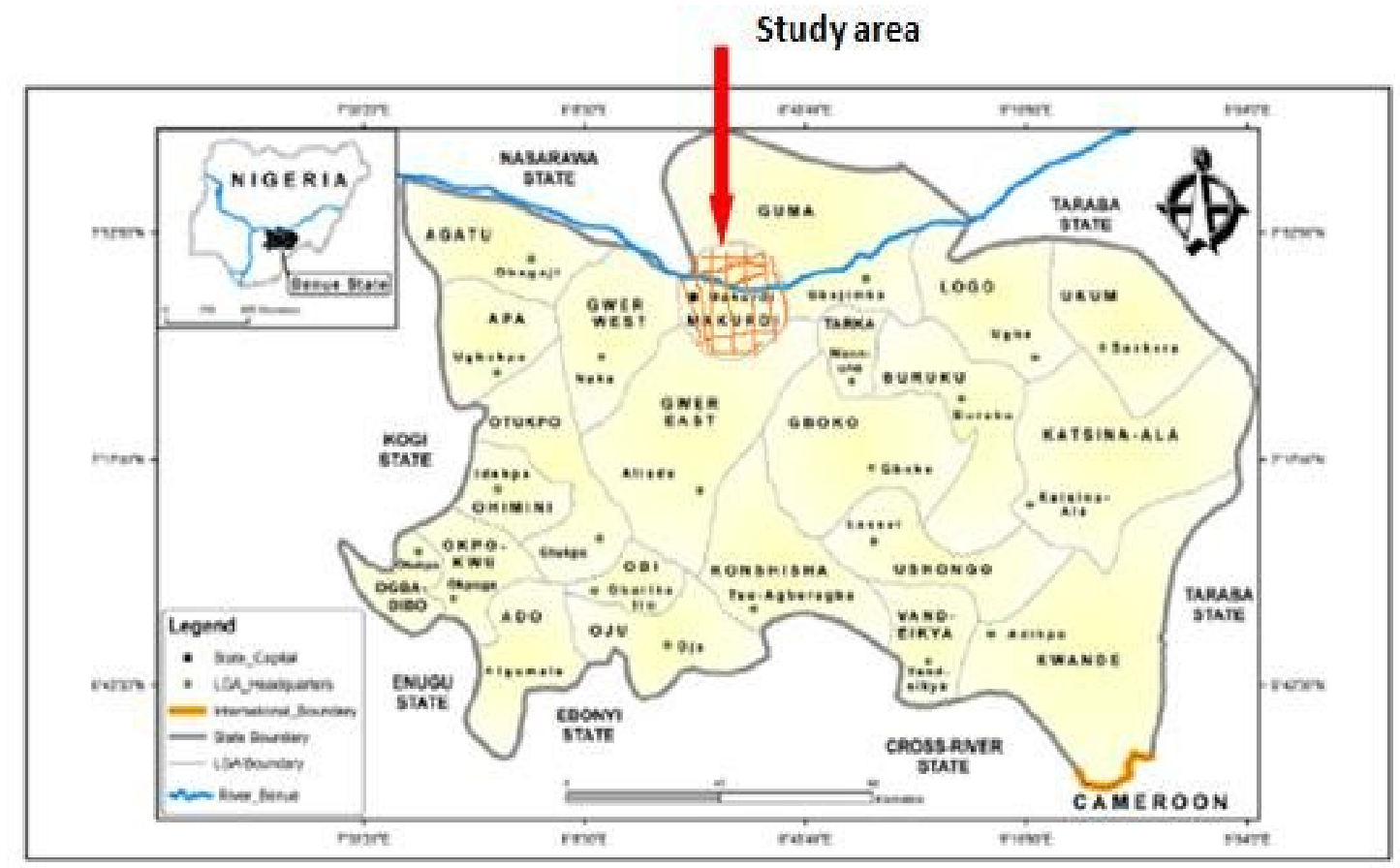

Figure 1: Map of Benue State showing the study area

Source: $\quad$ https://www.google.com/imgres 


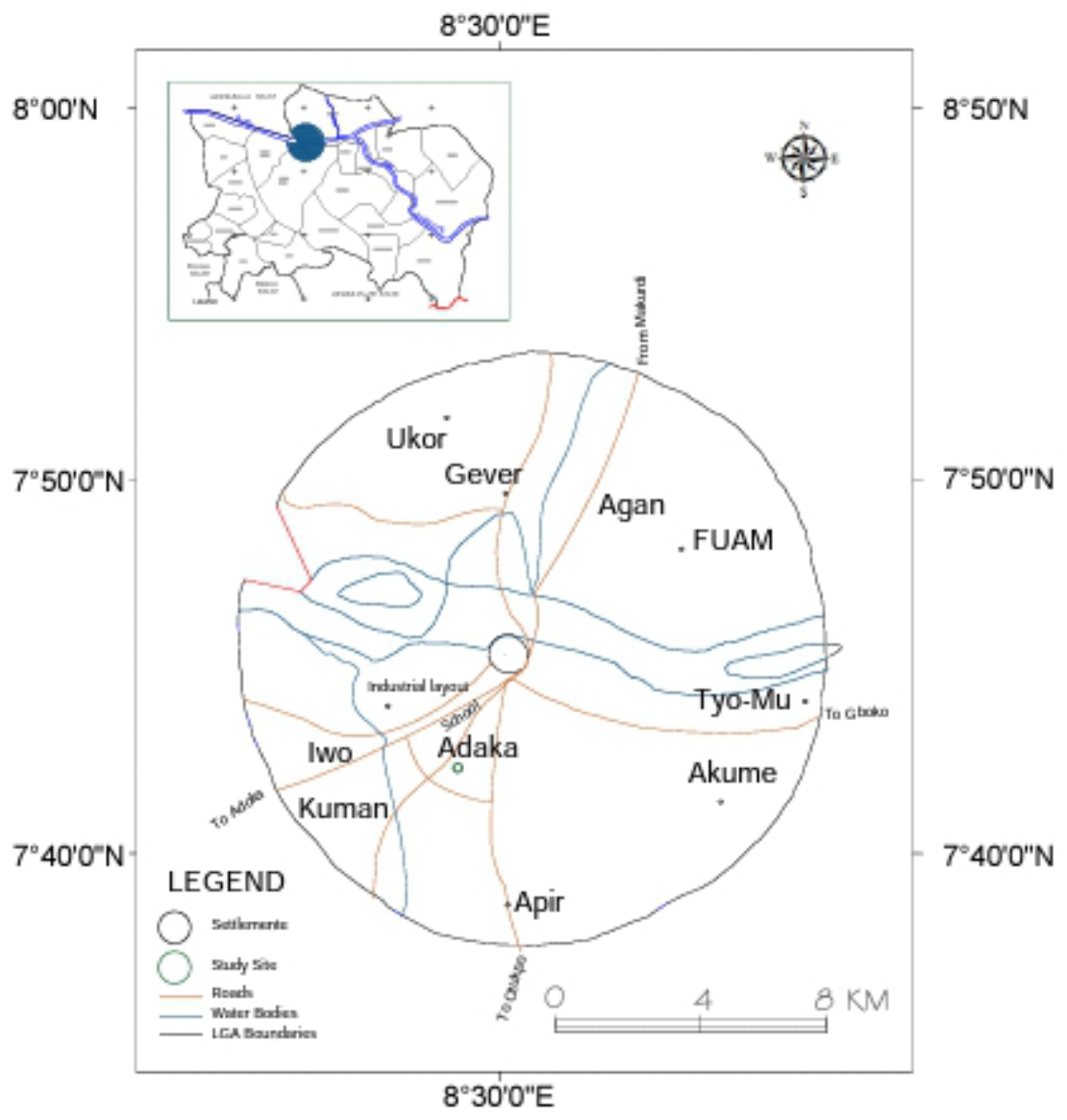

Figure 2: Map of Makurdi LGA showing the study area

Source: Ministry of Lands, Survey \& Solid Minerals, Makurdi

\section{Field work}

Reconnaissance soil survey was carried out to identify the soil types of the experimental site. This implies that auger samples of the soil was collected and analyzed in the laboratory for particle size distribution, exchangeable cation, cation exchange capacity (CEC) to determine percentage base saturation. Profile pits were sunk in each of the experimental site during the first and second year of the research (that is before the start and after the experiments).

\section{Soil Sample Collection and Preparation}

Soil samples were collected from the profile pits according to horizons, air-dried, crushed and sieved through a $2 \mathrm{~mm}$ mesh sieve, and analysed for physical and chemical properties.

\section{Laboratory Analysis}

The soil samples collected from the field were air-dried, gently crushed and sieved. The particle size distribution (PSD) was determined using Buoyoucos hydrometer method as described by Day (1965). Soil reaction $(\mathrm{pH})$ was determined using the electrometric method using $\mathrm{pH}$ meter in 1:1 soil: water ratio as described by Hesse (1971), and organic carbon was determined using the Walkey-Black method as described by Hesse (1971). The Macro Kjeldahl method was used to analyze for total N, while the Bray I method as described by IITA (1979) was used to analyze for available P. Exchangeable cations $(\mathrm{Ca}, \mathrm{Mg}, \mathrm{K}, \mathrm{Na})$ were determined from $\mathrm{NH}_{4} \mathrm{OAC}$ filtrate. Exchange acidity was determined using the Barium chloride-triethanolamine method as described by Peech (1965). The percentage base saturation was calculated by dividing the sum of exchangeable bases over the effective cation exchange capacity and multiplying by 100 . 


\section{Soil Classification}

From the results of the laboratory analyses and the field morphological characteristics, the soils encountered at the study area were classified according to the USDA Soil Taxonomy (Soil Survey Staff, 2010), into order, sub order, great group and sub groups categories, and were correlated with the FAO/UNESCO soil legend (FAO, 2010).

\section{Crop Sampling and Data Collection}

Central row plants were used for data collection. 10 plants from the middle rows were used to compute the score for each plot at 4, 6 and 8 WAP. The mean height from the 10 randomly selected plants from the middle rows were taken as the score for each plot. Growth parameters such as, plant height, number of leaf per plant, leaf area per plant, leaf area index, and stem diameter; yield components such as, ear weight, ear length, ear diameter, and grain yield were recorded at 14 WAP.

\section{Statistical Analysis}

Data collected on various growth and yield parameters were subjected to analysis of variance techniques using statistical analysis system software (SAS, 1997). The treatments means were separated using LSD test at 0.05 probabilities.

\section{Crop Management}

Maize seeds were planted in each of the treatment plots already prepared ( 3 seeds per hole) at a spacing of $90 \mathrm{~cm} \times 50 \mathrm{~cm}$ between and within rows. Prior to seed germination, the whole plots were sprayed with weed control chemicals (Glyphosyte and Atrazine) so as to suppress weed invasion in the plots. After germination, the maize seedlings were thinned to two seedlings per hole. Two weeks after planting, the maize seedlings were ring-dressed with the respective fertilizer rate according to the treatments indicated above and top dressed with urea fertilizer at four (4) weeks after planting. Improved maize variety (Orba Super II Hybrid) was used for the experiment. All other agronomic practices like hoeing, weeding, and so on were kept normal for all the treatments.

\section{Results and Discussion}

\section{Soil Physical and Chemical Properties}

The particle size analysis revealed that all horizons have clayey texture. The clay content ranged from 16.48 to $36.5 .35 \%$. The clay content in Makurdi and Lafia increased in clay content with depth which could be a result of pedogenic process of elluviation - illuviation going on in the soils. Sand was the dominant particle-size fraction in both the surface and subsurface horizons. The distribution of sand and silt contents did not follow a uniform trend of distribution down the profile pit. The sand fraction ranged from 51.23 to $69.52 \%$. Silt was the least of the three fractions and was about 8.76 to $14.00 \%$ in the surface and was nearly constant with soil depth. The soil was therefore, mainly sandy clay loam in the surface and sandy loam in the subsurface horizons. The low silt content corroborate the assertion of Akamigbo (1984) that soils of the savannah are low in silt as a result of the high degree and extent of weathering and leaching they have undergone and also. The soil texture reflects the nature of the parent material from which the soils are developed soil texture has an important role in the assessment of soil characteristics. The uptake capacity of the soil, which is an indicator of soil fertility, depends on the texture composition of the soil. According to Loide, (2004), as the percentage of clay particles and colloids contained in the soil increase, the content of plant nutrients bound by these particles and colloids increases as well. Thus the soil's nutrient binding capacity dictates how easily the nutrients not bound by soil particles can be washed out of the soil.

The chemical properties of the soils were very similar and were rated within the same range. Soil $\mathrm{pH}$ generally ranged from 6.6 to 7.0 indicating moderately acid soil and did not follow a uniform trend of distribution down the profile. Total nitrogen contents of the soils ranged from 0.12 
to $0.20 \mathrm{gkg}^{-1}$. Total nitrogen organic matter contents did not follow a uniform trend of distribution down the profile. The high total nitrogen and organic matter contents at the $\mathrm{Bt}_{1}$ horizon indicates little leaching losses in these soils, and could be attributed to the clayey nature of the soils. According to Landon (1991), low OC and low N content might be associated with continuous cultivation, lack of incorporation of fertilizer and relatively higher temperature of the study area. The crops planted must have exhausted the nitrogen in the soil. Again, the soil texture of this location could have contributed to the loss of nitrogen via leaching. It is important to always apply nitrogenous fertilizer in split so that the basal takes care of the vegetative growth while the top dressing takes care of the reproductive phase (Idem and Showemimo, 2004). Loss of $\mathrm{N}$ through denitrification and volatilization may also contribute to the low level of $\mathrm{N}$ in the area. Available $\mathrm{P}$ content of the soils was high (14.72 to $35.00 \mathrm{mgkg}^{-1}$ ). The high $\mathrm{pH}$ range in the soils (Table 2), suggests why available $\mathrm{P}$ was very high because it may not have being fixed in the soil. David et al., (2011) and Donald (2013) asserted that presence of Nickel in soil will enhance P availability in the soil. Among the exchangeable basic cations, calcium was generally the principal saturating cation in all the soils with values that ranged from 2.52 to $4.80 \mathrm{cmolkg}^{-1}$ and had irregular distribution pattern with soil depth. This was followed by $\mathrm{Mg}$ with values that ranged from 0.64 to $2.13 \mathrm{cmolkg}^{-1} \mathrm{but}$ generally decreased irregularly with soil depth. This was followed by potassium and sodium was the least. All the exchangeable bases are rated low in the soils. The low exchangeable bases of these soils in the study area may be due to the underlying materials, intensity of weathering, leaching, low activity clay, very low organic matter content and the lateral translocation of bases (Kang and Balasubramanian, 1990).

The CEC of the soil ranged from 6.03 to $9.52 \mathrm{cmolkg}^{-1}$ and are therefore, rated low. This can be attributed to the nature of clay minerals as well as low organic matter content of the soils. The higher the clay contents, the higher the CEC (Ufot 2012). Values of available phosphorus in the study area ranged from 14.72 to $35.00 \mathrm{mgkg}^{-1}$ and had irregular distribution pattern with depth. These values were rated high. The high available phosphorus encountered in the study area did not collaborate the findings of Eshett (1987) who remarked that most Nigerian soils have low phosphate reserves due to high phosphorus fixation. Base saturation in the study area ranged from 58.6 to $77.4 \%$. These values were rated high. Therefore, as the base saturation was above $50 \%$ in all cases, the soils have high fertility potential (which forms the separating index between fertile soils and non-fertile soils as stated by Landon, 1984). The high base saturation is probably associated with the presence of weathered minerals which release nutrients into the soil and their alluvial nature. A general correlation exists between the percentage base saturation and its $\mathrm{pH}$. As the base saturation is reduced owing to the loss in drainage of calcium and other metallic constituents, the $\mathrm{pH}$ is also lowered in a more or less definite proportion.

\section{Soil Classification}

The soils in the study area were classified using the USDA soil taxonomy (Soil Survey Staff, 2010) and correlated with the FAO/UNESCO legend of World Reference Base (FAO/UNESCO, 2010). The soils were classified at the order level as Alfisols because they had an argillic horizon and high base saturation. They were classified at the suborder level as Ustalfs due to ustic moisture regime and as Haplustalf and Typic Haplustalfs at the great group and sub-group levels respectively due to the simple soil profile which correlate approximately as Eutric Luvisols (FAO/UNESCO).

\section{Plant Properties}

The result showed that the application of different levels of fertilizer significantly improved the growth and yield of hybrid maize, "Oba super II". The application of fertilizer generally gave improvement in maize growth parameters measured at 8 WAP (Table 3). Leaf area and LAI were significantly different. However, plant height and stem diameter/plot were not significantly affected at all levels. There were no significant differences at the effects ranging from NPK 60:30:30 to $150: 75: 75 \mathrm{~kg} /$ ha fertilizer rate on leaf area and LAI during the 2017 and 2018 cropping season (Table 3). No significant differences were also observed in stem diameter at fertilizer rates 
ranging from NPK 60:30:30 to $120: 60: 60 \mathrm{~kg} / \mathrm{ha}$. The observed significant performance in growth parameters with the application of fertilizer could be attributed to the essential nutrient elements contained in the fertilizer which were capable of the increased photosynthetic efficiency (Dauda et al., 2008).

The performance of the maize during the 2017 and 2018 cropping seasons were not statistically different in all the growth traits evaluated with the different rates of fertilizer application. The greater number of leaves, plant height, LAI and stem diameter in maize occurred with higher fertilizer rates (NPK 150:75:75 kg/ha). This could be due to the ability of the fertilizer to supply the nutrient elements necessary to promote more vigorous growth, improve physiological activities in the plants, as well as improve the soil properties; hence resulting in the synthesis of increased photo- assimilates that enhanced maize yielding ability. LAI and grain yield had been observed to be positively correlated as long as the value of LAI was below 5 (Shortall and Liebhardt 1975). In this study, the highest mean value of LAI (0.46 in the 2017 and 2018 growing seasons, respectively) was also reached at the fertilizer rate of $0.8 \mathrm{t} / \mathrm{ha}$. Generally, all the traits were very strongly correlated with each other which suggest that, in the case of limited field resources, the performance evaluation of one or more of these traits may provide a reasonable index for the prediction of the probable performance of these other closely associated traits.

Table 2: Chemical Properties of the Study Areas before the Experiments

\begin{tabular}{|c|c|c|c|c|c|c|c|c|c|c|c|c|c|c|c|c|}
\hline \multirow[t]{2}{*}{ Horizon } & \multirow[t]{2}{*}{$\begin{array}{l}\text { Depth } \\
\text { (cm) }\end{array}$} & \multicolumn{2}{|c|}{$\begin{array}{l}\text { Particle Size } \\
\text { Distribution }\end{array}$} & \multirow[b]{2}{*}{ Clay } & \multirow[b]{2}{*}{$\begin{array}{l}\text { Text. } \\
\text { Class }\end{array}$} & \multirow[b]{2}{*}{$\begin{array}{c}\mathbf{p H} \\
\mathbf{H}_{2} \mathbf{O}\end{array}$} & \multirow[b]{2}{*}{$\begin{array}{c}\text { O.C } \\
\left(\mathrm{gkg}^{-1}\right)\end{array}$} & \multirow[b]{2}{*}{$\begin{array}{l}\text { T. N } \\
\left(\mathrm{gkg}^{-1}\right)\end{array}$} & \multicolumn{5}{|c|}{ Exchangeable Cation } & \multirow[b]{2}{*}{ TEB } & \multirow[b]{2}{*}{ CEC } & \multirow[b]{2}{*}{$\begin{array}{r}\text { BS } \\
(\%)\end{array}$} \\
\hline & & Sand & $\begin{array}{l}\text { Silt } \\
\text { (\%) }\end{array}$ & & & & & & \multicolumn{2}{|c|}{$\begin{array}{l}\text { A.P Ca } \\
(\mathbf{p p m})\end{array}$} & Mg & $\mathbf{K}$ & $\begin{array}{c}\mathrm{Na} \\
\text { (cmol }\end{array}$ & & & \\
\hline Ap & $0-12$ & 69.52 & 14.00 & 16.48 & SL & 6.9 & 3.54 & 0.13 & 20.64 & 3.14 & 2.13 & 0.20 & 0.11 & 5.58 & 9.52 & 58.6 \\
\hline $\mathrm{AB}$ & $12-27$ & 68.22 & 13.00 & 18.78 & SL & 6.8 & 3.78 & 0.20 & 25.00 & 2.52 & 1.05 & 0.23 & 0.14 & 3.94 & 6.42 & 61.4 \\
\hline $\mathrm{Bt}_{1}$ & $27-70$ & 52.52 & 13.36 & 34.12 & $\mathrm{CL}$ & 7.0 & 3.66 & 0.18 & 14.72 & 3.26 & 1.05 & 0.23 & 0.13 & 4.67 & 6.03 & 77.4 \\
\hline $\mathrm{Bt}_{2}$ & $\begin{array}{l}70- \\
133\end{array}$ & 51.23 & 12.45 & 36.32 & $\mathrm{CL}$ & 6.9 & 3.36 & 0.14 & 26.25 & 3.11 & 0.67 & 0.18 & 0.11 & 4.07 & 6.14 & 66.3 \\
\hline $\mathrm{C}$ & $\begin{array}{l}133- \\
141\end{array}$ & 54.89 & 8.76 & 36.35 & $\mathrm{CL}$ & 6.6 & 3.75 & 0.12 & 35.00 & 4.80 & 0.64 & 0.14 & 0.14 & 5.00 & 6.89 & 72.6 \\
\hline
\end{tabular}

Table 3: Morphology Variation by Concentration of Fertilizer in the Study Area from 2017 to 2018

\begin{tabular}{|c|c|c|c|c|c|}
\hline \multirow{2}{*}{$\begin{array}{l}\text { Fertilizer Rates } \\
\text { (kg/ha) }\end{array}$} & \multicolumn{5}{|c|}{ Plant Morphology } \\
\hline & $\begin{array}{l}\text { Plant Height } \\
(\mathrm{cm})\end{array}$ & No. of Leaves & $\begin{array}{l}\text { Leaf Area } \\
\left(\mathbf{m}^{2}\right)\end{array}$ & $\begin{array}{l}\text { Leaf Area } \\
\text { Index }\left(\mathbf{m}^{2}\right)\end{array}$ & $\begin{array}{l}\text { Stem Diameter } \\
(\mathrm{mm})\end{array}$ \\
\hline NPK 0:0:0 & $112.60 \pm 13.30$ & $11.37 \pm 0.35$ & $4.57 \pm 0.38^{\mathrm{b}}$ & $0.38 \pm 0.03^{b}$ & $65.77 \pm 3.52^{\mathrm{b}}$ \\
\hline NPK 60:30:30 & $123.00 \pm 12.60$ & $12.08 \pm 0.36$ & $5.51 \pm 0.40^{\mathrm{a}}$ & $0.45 \pm 0.03^{\mathrm{a}}$ & $76.64 \pm 4.47^{\mathrm{ab}}$ \\
\hline NPK 90:45:45 & $125.60 \pm 13.50$ & $12.03 \pm 0.37$ & $5.04 \pm 0.33^{\mathrm{ab}}$ & $0.42 \pm 0.02^{\mathrm{ab}}$ & $75.14 \pm 4.00^{\mathrm{ab}}$ \\
\hline NPK 120:60:60 & $127.70 \pm 17.20$ & $11.92 \pm 0.27$ & $5.18 \pm 0.27^{\mathrm{ab}}$ & $0.43 \pm 0.02^{\mathrm{ab}}$ & $76.25 \pm 3.46^{\mathrm{ab}}$ \\
\hline NPK 150:75:75 & $130.60 \pm 16.60$ & $12.30 \pm 0.30$ & $5.50 \pm 0.19^{\mathrm{ab}}$ & $0.45 \pm 0.01^{\mathrm{ab}}$ & $79.88 \pm 3.59^{\mathrm{a}}$ \\
\hline P-Value & $0.92^{n s}$ & $0.38^{n s}$ & 0.04 & 0.04 & 0.03 \\
\hline
\end{tabular}

Means on the same column with different superscript are statistically significant $(p<0.05)$; ns $=$ not significant 
Table 4: Yield Variation by Concentration of Fertilizer in the study area from 2017 to 2018

\begin{tabular}{|c|c|c|c|c|}
\hline \multirow{2}{*}{$\begin{array}{l}\text { Fertilizer Rates } \\
\text { (kg/ha) }\end{array}$} & \multicolumn{4}{|c|}{ Yield Parameters/Ha } \\
\hline & Ear Weight (kg) & $\begin{array}{l}\text { Ear Length } \\
\text { (cm) }\end{array}$ & $\begin{array}{l}\text { Ear Diameter } \\
(\mathrm{cm})\end{array}$ & $\begin{array}{l}\text { Grain Yield } \\
\text { (kg) }\end{array}$ \\
\hline NPK 0:0:0 & $129.80 \pm 22.60$ & $11.81 \pm 0.71^{\mathrm{b}}$ & $153.80 \pm 12.70^{\mathrm{b}}$ & $1.62 \pm 0.21$ \\
\hline NPK 60:30:30 & $178.00 \pm 26.00$ & $14.55 \pm 0.83^{\mathrm{a}}$ & $186.00 \pm 23.40^{\mathrm{ab}}$ & $2.54 \pm 0.25$ \\
\hline NPK 90:45:45 & $173.00 \pm 25.80$ & $14.35 \pm 0.71^{\mathrm{a}}$ & $201.80 \pm 13.90^{\mathrm{a}}$ & $2.52 \pm 0.36$ \\
\hline NPK 120:60:60 & $175.00 \pm 21.30$ & $14.63 \pm 0.60^{\mathrm{a}}$ & $205.50 \pm 13.00^{\mathrm{a}}$ & $2.65 \pm 0.24$ \\
\hline NPK 150:75:75 & $172.30 \pm 20.00$ & $15.16 \pm 0.61^{\mathrm{a}}$ & $220.20 \pm 12.70^{\mathrm{a}}$ & $2.82 \pm 0.29$ \\
\hline P-Value & $0.56^{n s}$ & 0.01 & 0.04 & $0.49^{n s}$ \\
\hline
\end{tabular}

Means on the same column with different superscript are statistically significant $(\mathrm{p}<0.05)$; $\mathrm{ns}=$ not significant

The results further indicated that fertilizer significantly enhanced maize yield in the two cropping seasons (Table 4). The use of fertilizer produced more vigorous maize plants having significantly bigger average ear weight, ear length and ear diameter than when fertilizer was not applied. The maize grain yield per hectare increased significantly with each progressive increase to the highest fertilizer rate. Thus, the highest maize grain yield of $2.82 \mathrm{~kg} / \mathrm{ha}$ was obtained with the use of NPK 150:75:75 kg/ha in 2017 - 2018 cropping seasons. Fertilizer application produced an appreciable maize grain yield of $2.82 \mathrm{~kg} / \mathrm{ha}$ (averaged over the two growing seasons). Without the application of fertilizer, the average maize grain yield from this study was $1.62 \mathrm{~kg} / \mathrm{ha}$ which is greater than yields generally obtained by peasant farmers who are not able to afford any fertilizer input in this agro-ecological zone.

\section{Conclusion}

Since there was no significant difference between the fertilizer rates from the above results, it could be concluded that the minimum application rate should be used in cultivating maize in Alfisols of Makurdi instead of the highest or the blanket recommendation which involved higher cost. This implies that the yield potential by farmers in this study area can be successfully maximized with the application of NPK $60: 30: 30 \mathrm{~kg} / \mathrm{ha}$ fertilizer.

\section{References}

[1] Akamigbo, F.O.R. (1984). The Accuracy of Field Texture in a Humid Tropical Environment. Soil Survey and Land Evaluation 493: 63-70

[2] Burke, K., Dessauvagie, T.F.J. and Whiteman, A.J. (1970). Geological History of the Benue Valley and Adjacent Area. In African Geology (T.F.J. Dessauvagie and A.J. Whiteman, Eds). Univ. of Ibadan Press, Nigeria

[3] Fanan, U., and Felix, K. (2014). Analysis of the Spatial Distribution of Health Facilities in Benue State, Nigeria, Public Health Research 2014, 4(5): 210-218

[4] Day, P.R. (1965). Particle fraction and particle size analysis. In: C.A. Black (ed), Methods of Soil Analysis, Agron. 9. ASA, Madison, Wisconsin, USA, Pp547-577

[5] Hesse, R.P. (1971). A text book of soil chemical analysis. John Murray Publishers Ltd., London. Pp8-184

[6] Kang, B.T. and Balasubramanian, V. (1990). Long-term fertilizer trials in Alfisols in West Africa. In Transactions of XIV International soil science study congress, Kyoto, Japan (vol. 4) Kyoto, Japan: ISSS. Kang, B.T. (1993). Changes inn Soil Chemical Properties and Crop Performance with Continuous Cropping on an Entisol in the Humid Tropics. In Mulongoy, K. and R. Merckx (eds) Soil Organic Matter and Sustainability of Tropical Agriculture: John Willey and Sons (UK), KU Lenven (Belgium) and IITA (Nigeria) pp 297-305 
[7] Landon, J.R. (1984). Booker Tropical Manual. A Handbook for Soil Survey and Agricultural Land Evaluation in the Tropics and Subtropics. Booker Agricultural International Ltd. UK.

[8] Loide, V. (2004). About the effect of the contents and ratios of soils available $\mathrm{Ca}, \mathrm{K}$ and $\mathrm{Mg}$ in liming of acid soil. Agricultural Research Center, Teaduse 4/6. Agronomy Research 2 (1), $71-82$

[9] Madu A.J.C. and Ozibo B.N.(2017). Geology of parts of Gboko and Makurdi Local Government Areas, Benue State, Nigeria. International Journal Geology and mining 2(2): 064-070

[10] Olaoye, G. and Adegbesen, N. O. (1991). Utilization and processing of maize. IITA Research Guide No. 35. Training Program, International Institute of Tropical Agriculture (IITA) 29p

[11] SAS, (1997). SAS Statistical Methods. SAS Institute Inc., Cary, NC., USA

[12] Ufot, U. O. (2012). Soils and the Environment for Colleges and Universities. Shadow Pub. Ltd, Owerri, Nigeria. Pp1635 